\title{
Preventing iron deficiency in preschool children by implementing an educational and screening programme in an inner city practice
}

\author{
John James, Pauline Lawson, Paul Male, Anthony Oakhill
}

\begin{abstract}
Objective-To assess the feasibility and acceptability of screening young children for iron deficiency in a deprived inner city practice and to assess the effects of a programme of dietary education.

Design-Prospective study of children in general practice, comparison with historical controls.

Setting-A deprived inner city practice.

Patients - 127 Children aged 13-24 months. Findings were compared with those in 110 children of the same age studied previously.

Interventions-All mothers received dietary education antenatally and in the first year after giving birth. Screening for iron deficiency (defined as mean cell volume $<\mathbf{7 5} \mathbf{f l}$ and haemoglobin concentration $<105 \mathrm{~g} / \mathrm{l}$ ) and haemoglobinopathy (when appropriate) was offered for all children attending for immunisation against measles, mumps, and rubella over 12 months; capillary blood samples were taken after immunisation.
\end{abstract}

Main outcome measures - Uptake of the screening programme expressed as the percentage of all children eligible for immunisation who were screened, and the effectiveness of the dietary education as shown by the prevalence of iron deficiency in the two groups.

Results -Altogether, 122 of the 127 (96\%) children who attended for immunisation had their haemoglobin concentration and mean cell volume measured; $90 \%$ of all children aged 13-24 months in the practice were screened. Dietary education, clinical procedures, and counselling were incorporated successfully into the clinic's work. Ten children $(8 \%)$ were iron deficient, all of whom responded to iron supplements, and eight had a haemoglobinopathy trait. In the previous study 110 children $(70 \%)$ had been screened and 28 children $(25 \%)$ had been iron deficient. The two groups were similar in terms of sex, social class, and ethnic group.

Conclusions-Screening young children for iron deficiency, sickle cell disease, and thalassaemia when they attended for immunisation was acceptable and successful in a socially deprived inner city practice. Dietary education may have accounted for some of the reduction in the prevalence of iron deficiency that occurred over the two years.

\section{Introduction}

The importance of diagnosing and treating iron deficiency in childhood has been recognised and routine screening suggested. ${ }^{1-4}$ Iron deficiency is associated with developmental delay and behavioural disorder in children, and developmental performance rapidly improves when it is corrected. ${ }^{-12}$ Nevertheless, the acceptability and logistics of screening for iron deficiency have been questioned, ${ }^{\prime}$ and a recent report of the British Paediatric Association's working party on child health screening indicated the need for further research before routine surveillance for iron deficiency was recommended.'

This inner city practice in Bristol serves an area characterised by widespread deprivation; two fifths of the children registered with the practice are members of single parent families, and half are members of an ethnic minority, principally West Indian. A study carried out between July 1986 and January 1987 had indicated the need for routine screening for iron deficiency ${ }^{14} ;$ screening had been offered to 527 children under 5 years of age, and 365 children (uptake $70 \%$ ) had had their capillary haemoglobin concentration and mean cell volume estimated. The prevalence of iron deficiency (defined as a mean cell volume $<75 \mathrm{fl}$ or a haemoglobin concentration $<105 \mathrm{~g} / \mathrm{l}$, or both) was $15.9 \%$. Iron deficiency was more common in children in the second year of life $(25 \%)$ and in children from an ethnic minority $(24 \%)$. There were no differences in either social background or ethnic group between the screened and unscreened children; the findings were therefore considered to be generalisable to the practice population.

As a result of that study we introduced a programme of dietary education to prevent iron deficiency to all parents, both antenatally and in the first postnatal year. Screening for iron deficiency was offered for all children in their second year of life. Furthermore, as the baby clinic was well attended, with uptake of measles vaccine being over $90 \%,{ }^{15}$ screening was offered to children when they attended for immunisation against measles (later measles, mumps, and rubella). At the same time haemoglobin electrophoresis was done for children who were members of an ethnic minority.

The aims of this study were twofold: firstly, to assess whether routine screening would be acceptable to patients, as measured by the uptake rate, and whether it could be incorporated easily into the work of the practice; and, secondly, to assess the effectiveness of the programme of dietary education by comparing the prevalence of iron deficiency with that found in the original study.

\section{Subjects and methods}

The primary health care team is based in a health centre and comprises five doctors (serving 11000 patients), four attached health visitors, four treatment room nurses, and two midwives; all work together closely. Dietary education to prevent iron deficiency was introduced in 1987. The midwives and health visitors discuss with the parents the importance of dietary iron, the consequences of iron deficiency, and the results of our previous study. A diet sheet produced by the senior dietitian at Bristol Children's Hospital listing food rich in iron as well as those foods acceptable 
to vegetarians ( $12 \%$ in the previous study) is given to all mothers. In addition, the reasons for screening all children when they attend for immunisation are discussed at an early stage.

All children attending the baby clinic for immunisation against measles or measles, mumps, and rubella between June 1988 and May 1989 were offered screening for iron deficiency. All children were seen before immunisation by one of the general practitioners. Capillary blood samples were taken by the treatment room nurses after the immunisation procedure. Blood $(0.5 \mathrm{ml})$ was collected in a Microvette EDTA tube and processed in a Coulter $S$ counter. Haemoglobin electrophoresis was also carried out for children who might be at risk of having or being carriers of a haemoglobinopathy. None of these children had been investigated in the previous study. All children found to be iron deficient or for whom haemoglobin electrophoresis yielded abnormal results were recalled and their parents counselled by the treatment room staff. All children with iron deficiency were treated with ferrous fumarate syrup, and haemoglobin, mean cell volume, and reticulocyte count were estimated two to three weeks later.

To compare these children with those in the previous study we studied only children aged 13-24 months. Uptake of immunisation against measles or measles, mumps, and rubella was calculated by scrutinising the notes of all children eligible for immunisation during the study, and overall uptake of the screening procedure was calculated from this. The two groups were compared for age and ethnic group, and the mean age of each group was estimated.

\section{Results}

Altogether 122 of 127 children aged 13-24 months who attended for immunisation against measles or measles, mumps, and rubella were screened for iron deficiency. Haemoglobin electrophoresis was carried out for all children who were members of an ethnic minority. Uptake of immunisation was $93 \%$ (127/136), giving an overall uptake of the screening procedure of $90 \%$. The children screened did not differ from the children in the previous study in age or sex, but a slightly smaller proportion of children were of AfroCaribbean parentage and a slightly larger proportion white (table I).

Ten children (8\%) were found to be iron deficient, compared with 28 out of $110(25 \%)$ in the previous study. Seven of these 10 children $(6 \%)$ had a haemoglobin concentration less than $105 \mathrm{~g} / \mathrm{l}$ (table II), compared with $12(11 \%)$ previously. All these children

TABLE I - Demographic characteristics of children aged 13-24 month in present (1988-9) and previous (1986-7) studies of prevalence of iron deficiency

\begin{tabular}{lcc}
\hline & $1988-9$ & $1986-7$ \\
\hline No studied & 122 & 110 \\
Mean age (months) & 16 & $16 \cdot 6$ \\
Sex (No (\%)): & $65(53)$ & $59(54)$ \\
$\quad$ Male & $57(47)$ & $51(46)$ \\
$\quad$ Female & $66(54)$ & $56(51)$ \\
Ethnic group $($ No $(\%)):$ & $51(42)$ & $50(45)$ \\
$\quad$ White & $2(2)$ & $2(2)$ \\
Afro-Caribbean or mixed parentage & $3(2)$ & $2(2)$ \\
Vietnamese & & \\
Indian subcontinent & & \\
\hline
\end{tabular}

TABLE II - Prevalence of iron deficiency in children aged 13-24 months in present (1988-9) and previous (1986-7) studies

\begin{tabular}{lcc}
\hline & $1988-9$ & $1986-7$ \\
\hline No $(\%)$ of children screened & $122(90)$ & $110(70)$ \\
No $(\%)$ iron deficient & $10(8)$ & $28(25)$ \\
Mean haemoglobin $(\mathrm{g} / \mathrm{l})$ & 119 & 117 \\
\hline
\end{tabular}

TABLE III-Prevalence of iron deficiency in children aged 13-24 months by ethnic group in present (1988-9) and previous (1986-7) studies. Figures are numbers (percentages)

\begin{tabular}{llc}
\hline Ethnic group & $1988-9$ & $1986-7$ \\
\hline White & $4(6)$ & $7(13)$ \\
Afro-Caribbean or mixed parentage & $4(8)$ & $18(36)$ \\
Vietnamese & $2(100)$ & $2(100)$ \\
Indian subcontinent & 0 & $1(50)$ \\
\hline
\end{tabular}

were given iron supplements and showed a rise in haemoglobin concentration. The prevalence of iron deficiency in children of Afro-Caribbean parentage was much lower in this study than the previous one (table III). Four children were found to have sickle cell trait, one haemoglobin $\mathrm{C}$ trait, and three $\beta$ thalassaemia trait.

\section{Discussion}

Despite general agreement that iron deficiency is an important treatable condition in childhood, questions have been raised about the acceptability and effectiveness of a screening programme. ${ }^{213}$ The results of this study suggest that parents, despite living in conditions of great deprivation, will accept this screening test for their children. The reasons for the high uptake are probably the good relationship that has been forged between parents and members of the primary health care team and that the blood samples are taken by members of staff known to the parents. Furthermore, the parents regarded screening for haemoglobinopathies as important. Offering screening at the time of immunisation against measles, mumps, and rubella made organisation simple as parents are routinely sent appointments to attend for immunisation; counselling had taken place at an earlier stage. In the previous study children had been invited to the health centre's "iron clinic" specifically for screening for iron state and no other health services had been offered. This may explain why the uptake in that study was just $70 \%$.

Just $8 \%$ of the children in this study were iron deficient compared with $25 \%$ in the previous study. We believe that the results from the two studies can be compared as in the earlier study there were no sociological or ethnic differences between those who were screened and those who were not. Furthermore, there have been no obvious changes in the social milieu of the area; if anything, deprivation has become more evident. The criteria used to diagnose iron deficiency were identical in both studies.

Nevertheless, caution must be exercised in interpreting these results. Although the prevalence of anaemia (haemoglobin concentration $<105 \mathrm{~g} / \mathrm{l}$ ) was reduced, the reduction was not large. The definition of anaemia and iron deficiency has been much discussed. $^{+7916}$ Furthermore, others have measured serum ferritin concentration, red cell protoporphyrins, and transferrin saturation in assessing iron state. ${ }^{17}$ In our study haemoglobin concentration and mean cell volume were the only variables measured, and our definitions of iron deficiency may underestimate the overall prevalence. We considered that additional measurements were beyond the scope of this general practice investigation.

The reduction in prevalence in iron deficiency is probably due to several reasons but must to some degree have been influenced by the health education programme introduced after the results of the first study were known. This entailed a combined approach by health visitors, midwives, and treatment room nurses, who gave all parents a diet information sheet. The dietary education was integrated into general health education given by members of the primary health care team. Interestingly, two large scale studies 
in the United States have shown a declining prevalence of anaemia in children from both low income and middle class families. ${ }^{14}$ The supply of free formula and cereal rich in iron and of juice supplemented with vitamin $\mathrm{C}$ (the special supplemental food programme for women, infants, and children) to low income families ${ }^{21}$ and better education of middle class families are suggested explanations. Stockman, commenting on these studies, argued that their findings, though encouraging, underestimated the prevalence of iron deficiency'; the behavioural and developmental disturbances associated with iron deficiency may occur in the absence of anaemia. ${ }^{9-12}$

Although this study showed that the prevalence of iron deficiency has fallen, iron deficiency still remains a problem. We will continue to screen all young children and treat those found to be iron deficient. It is also important that all children who may have a haemoglobinopathy are identified at an early age and their parents counselled. Taking capillary blood samples is simple and acceptable to parents and took little time.

We thank Hazel Digby, Vivienne Giles, and Lyn Harbird (treatment room nurses); Beth Samphire, Jenny Theed, Jane Sendles, and Margaret Douglas (health visitors); Jan Drakeford, (senior dietitian); Kathy Edwards (midwife); and Mavis Bevan and Anne Gaulton for their invaluable help.

1 Addy DP. Happiness is: iron. Br.Med f 1986;292:969-70.

2 Anonymous. Iron deficiency - time for a community campaign? (Editorial Lancet $1987 ;$ i: $1+1-2$
3 Illingworth RS Anaemia and child health surveillance, Arch Dis Child 1986;61:1151-2.

4 Stockman JA. Iron deficiency anaemia: have we come far enough? JAMA 987;258:16+5-7

5 Walter $T$, Kovalaskys J, Steel A. Effect of mild iron deficiency on infant mental development scores. F Pediatr 1983;102:519-22.

6 Pollitt E, Soemantri AG, Yunis F, Scrimshaw NS. Cognitive effects of iron deficiency anaemia. Lancet 1985;i: 158 .

Lozoff B, Brittenham GM. Behavioral aspects of iron deficiency. Prog Hematol 1985;14:23.

8 Aukett MA, Parks YA, Scott PH, Wharton BA. Treatment with iron increases weight gain and psychomotor development. Arch Dis Child 1986;61:84958.

9 Oski FA, Honig AS. The effects of therapy on the developmental scores of ron-deficient infants. 7 Pediatr 1978;92:21.

10 Lozoff B, Brittenham GM, Viteri FE, et al. The effects of short-term oral iron therapy on developmental deficits in iron-deficient anemic infants. $\mathcal{f}$ Pediatr 1982:100:351.

11 Oski FA, Honig AS, Helu B, et al. Effect of iron therapy on behavior performance in non-anemic, iron-deficient infants. Pediatrics 1983;71:877.

12 Lozoff $\mathrm{B}$, Brittenham GM, Wolf AW, et al. Iron deficiency anemia and iron therapy effects on infant developmental test performance. Pediatrics 1987;79:981.

13 Hall DMP. Health for all children: a programme for child health surveillance. Oxford: Oxford Medical Publishers, 1989:34-6.

It James J, Evans J, Male P, Pallister C, Hendrikz J, Oakhill A. Iron deficiency in inner-city pre-school children: development of a general practice screening programme. 7 R Coll (ien Pract 1988;38:250-2.

15 James JA, Clark C, Rossdale $M$. Child care in the community. Lancet $1986 ; \mathrm{i}: 856$.

16 Parks YA, Aukeu MA, Murray JA, Scott PH, Wharton BA. Mildly anaemic toddlers respond to iron. Arch Dis Child 1989;64:400-1.

17 Dallman PR, Yin R. Johnson C. Prevalence and causes of anemia in the United States, 1976 to 1980. Am f Clin Nutr 1984;39:437.

18 Yip R, Binkin NJ, Fleshood L, et al. Declining prevalence of anemia among low income children in the United States. FAMA 1987;258:1619-23.

19 Yip R, Walsh KM, Goldfarb MG, Binkin NJ. Declining prevalence of anemia in a middle-class society. A pediatric success story? Pediatrics 1987;80: $330-4$

20 Miller $V$, Sevaney S, Deinard $A$. Impact of the WIC programme on the iron status of infants. Pediatrics 1985;75:100.

Accepled 23. August 1989
Accident and emergency

Emergency Medicine: the Essential Update. G R Schwarz, N Bircher, B K Hanke, et al. (Pp ix +336 ; figs; $£ 32$. Philadelphia: Saunders, 1989. Distri buted by Harcourt Brace Jovanovich. ISBN 0-7216-2459-6.

AIDS

Confronting AIDS: Update 1988. Institute of Medicine National Academy of Sciences. (Pp $\mathrm{x}+239 ;$; 13.75 paperback.) Washington DC. Nation Academy Press, 1988. Distribured by John Wiley and Sons. ISBN 0-309. 03879-0.

\section{Addiction}

Addicts Who Survived: An Oral Histor of Narcotic L'se in America 1923-65. 1) Courtwright, H Joseph, D Des Jarlais. Ppxvi + 399; figs; \$24.95.) Knoxville: The Unwersity of Tennesse

Alcohol Education: a Handbook for Health and Welfare Professionals. B Howe. (Pp xiv +177 ; $\$ 9.95$ paperback.) London: Tavistock/Routledge 1989. ISBN 0-415-01891-9.

If You Really Loved Me... How To Survive Any Addiction in the Fumily. J Survive Any Addiction in the Family. 56.99 paperback.) London: Macmil lan, 1989. ISBN 0-333-48265-4.

Relapse and Addictive Behaviour. Ed M Gossop. (Pp viil + 305; figs; $\{29.95$. London: Tavistock/Routledge, 1989. ISBN 0-415-02354-8.

Treaing Drug Abusers. Ed (; Bennet. (Pp vi 201 ; figs; $\{25$.) London: Tavistock/Routledge, 1989. ISBN $0-415$. $02039-5$.

\section{Alternative medicine}

Alternative Health Care for Children: Comprehensive Guide for Parents. E d ong. (Pp 128; figs; $£ 3.99$ paperback.) Wellingborough: Thorson, 1989 ISBN 0-7225-1553-7.

Alternative Maternity. N Wesson. (Pp $\mathrm{x}+194$; figs; $£ 5.99$ paperback. London: Optima, 1989. ISBN 0-356$15+12-2$

\section{Anaesthesia}

Anaesthesia and the Brain: Climical, Functional, Metaholic, and l'ascular Correlates. J D Michenfelder. (Pp xi 215; figs; $\{27.50$.) New York: Churchill Livingstone, 1989. ISBN $0-4+43-$ 08628-1.

Introduction to Regional Anaesthesia. $\mathrm{D}$ B Scott. (Pp 96; figs; colour plates: £19.95 paperback. Connecticut: A pleton and Lange, 1989. Distributed by Prentice-Hall. ISBN 0-8385-4390Oxford Medical Enginecring Series. "Anaestheric and Extracorporeal Gas "Anaesthe " and Extracorporeal Gas "Transfer." K L Dorrington. (Pp x Press, 1989. ISBN 0-19-857632-3.

Techniques of Regional Anaesthesia. B Scott. (Pp 224; colour plates; $£ 69$.) Connecticut: Appleton and Lange/ ice-Hall. ISBN 0-8385-8844-1.

Anatomy

Fundamental Anatomy for Operative General Surgery. S J Snooks, R F M Wood. (Pp iv + 91; figs; 211.95 paperback.) London:

\section{Biology}

A Guide to Modern Biologv: Genetics, Cells and Systems. E Lawrence. (Pp xviii +507; figs; $\{9.95$ paperback.) Harlow: Longman, 1989. ISBN 0582-44272-y.

Modern Cell Biologv. Vol 8. "Functional Epithelial Cells in Culture." Ed K S Matlin, J D Valentich. Series editor B H Satir. (Pp xii +463 ; figs; $\$ 79.50$.) New York; Liss, 1989. Distributed by John Wiley and Sons. ISBN (0-84513307-1.

\section{Cardiology}

Critical Care Cardiologv. Fd R J Hen- ning, A Grenvik. ( $\mathrm{Pp} \times \mathrm{xi}+566$; figs; c60.) New York: Churchill Living stone, 1989. ISBN 0-443-08565-X. Diseases of the Cardiac l'alves. R J C Hall, D G Julian. (Pp viii +376 ; figs: 50.) Edinburgh: Churchill Livingstone, 1989. ISBN 0-4+3-03479-6.

\section{Obstetrics and gynaecology}

A Colour Atlas of Gynaecological Cytologv. O A N Husain, E B Butler. (Pp 12; colour plates; $\mathcal{L 4 0}$.) London: Wolfe Medical, 1989. ISBN 0-72340913-7.

Diseases of the Fetus and Newborn: Pathologv, Radiologv and Genetics. Ed G B Reed, A E Claireaux, A D Bain. Pp xviii +812; figs; £135.) London: Chapman and Hall Medical, 1989 ISBN 0-412-27990-8.

Fetal Medicine. Vol 1. Ed C H Rodeck. (Pp vi + 314; figs; £35.) Oxford: Blackwell Scientific, 1989. ISBN 0-63201972-7.

Having a First Baby: Experiences in 1951 and 1985 Compared. B Thompson, C Fraser, A Hewitt, D Skipper. (Pp xviii +166; figs; 114.50 paperback.) Aberdeen: Aberdeen University Press, 1989. ISBN 0-08036596-5.

Intrauterine Growth Retardation: a Practical Approach. T L Gross, R J Sokol. (Pp xvi+237; figs; $\{33$. Chicago: Year Book Medical, 1989 Distributed by Wolfe Medical Publications. ISBN 0-8151-4006-1.

\section{Radiolog}

Digital Subtraction Imaging in Infants and Children. Ed E N Faerber. (Pp xi+ 193; figs; \$42.) ISBN 0-87993-340-2.

\section{Surgery}

Cardiothoracic Trauma. P N Symbas. (Pp xi +404; figs; 555.75 .) Philadelphia: Saunders, 1989. Distributed by 0-7216-2827-3.

100 Case Histories for the HRCS. L C Barr, M R Pittam. Pp viii + 200; $\$ 9.95$ paperback.) Edinburgh: Churchill Livingstone, 1989. ISBN 0-44303296-3.

The Professional Nurse Clinical Skills Series. "Thoracic Surgery." M A Foss. (Pp viii +168 ; figs; $£ 15$ paperback. ondon: Cornish, 1989. ISBN $1-870065-08-5$

\section{Terminal care}

Nursing the Dving. D Field. Pp vii $175 ; \quad\{8.95$ paperback.) London Tavistock/Routledge, 1989. ISBN 0-415-0105+-3.

So Birchester Needs a Hospice.... Guide for Those Concerned with the Establishment and Operation of Hospices. R Harper, A W M Ward, L Westlake, B T Williams. (Pp 42; $\{5$ paperback, including postage.) 1989. Obtainable from University of Shef field, Department of Community Medicine, Medical School, Sheffield S10 2RX.

\section{Third World}

Monographs from the African Studies Centre, Leiden. "Intervention in Child Nutrition: Evaluation Studies in Kenya."J Hoorweg, R Niemeijer. (I'p xii+173; figs; £20.) London: Kega Paul, 1989. Distributed by John Wiley and Sons. ISBN 0-7103-0276-2.

\section{Tropical medicine}

Tropical Medicine and Parasitology. $\mathbf{R}$ Goldsmith, D Heyneman. (Pp xxiv 942; figs; $\{24.95$ paperback.) London: Prentice-Hall International, 1989. ISBN 0-0835-9031-4.

Ultrasonics

Clinics in Diagnostic Ultrasound. Vol 24. "Neonatal and Paediatric Ultrasonography." Ed D S Babcock. (Pp xi+275; figs; $£ 37.50$.) New York: rchill Livings

Urology

Urology Annual 1989. Vol 3. Series

editor S N Rous. (Pp 14+266; figs; £54.50.) Connecticut: Appleton and Lange, 1989. Distributed by Prentice Hall International, ISBN $0-8385$ 9320-8.

Urology for Nurses. J P Blandy, J Moors. (Pp viii +268 ; figs; $£ 12.95$ paperback.) Oxford: Blackwell Scientific, 1989. ISBN 0-632-01686-8.

\section{Miscellaneous}

Medicine and Culture: Notions of Health and Sickness in Britain, the US, France and West Germany. L Payer. (Pp 204; $£ 12.95$ paperback.) London: Gollancz, 1989. ISBN 0-575-04532-9.

Roundsmanship '89: a Year Book Guide to Clinical Medicine. R D Feigin, E J Quilligan $e t$ al. Editor-in-Chief B B Dan. (Pp xv +243; figs; $\$ 19.95$ paperback.) Chicago: Year Book Medical 